\title{
The effects of fin height, fin-tube contact thickness and louver length on the performance of a compact fin-and-tube heat exchanger
}

\author{
Kourosh Javaherdeh ${ }^{1 *}$, Ahmad Vaisi ${ }^{1}$, Rouhollah Moosavi ${ }^{2}$ \\ ${ }^{1}$ Department of Mechanical Engineering, University of Guilan, Rasht 4199613776, Iran \\ ${ }^{2}$ Department of Mechanical Engineering, Yasouj University, Yasouj 7591874934, Iran
}

Corresponding Author Email: Javaherdeh@guilan.ac.ir

https://doi.org/10.18280/ijht.360307

Received: 21 April 2017

Accepted: 9 March 2018

\section{Keywords:}

compact heat exchanger, louvered fins, experimental, numerical, pressure drop, Nusselt number

\begin{abstract}
In this paper, the effects of fin height, louver length and fin-tube contact thickness on the amount of heat transfer and pressure drop in a compact louvered fin-and-tube heat exchanger were studied experimentally and numerically using the $\varepsilon-N T U$ method. The effects of fintube contact thickness (with the variations of this thickness being more than or less than fin thickness variation) and fin height and also the relationship between Louvre length and fin height were examined. To validate the modeling, first, the numerical model was compared with an experimental prototype, and a good agreement was observed between the experimental and numerical results. The modeling results indicate that the increase in the fin-tube contact thickness, until the contact thickness becomes equal to fin thickness, leads to the improvement of heat exchanger performance; but beyond that, it is ineffective. Also, heat exchanger performance improves with the increase of louver length at a fixed fin height. According to the results, the minimum Louvre length should be $1.0 \mathrm{~mm}$ less than the fin height. An analytical equation relating Louvre length to fin height has been obtained, which agrees with model results by up to $98 \%$.
\end{abstract}

\section{INTRODUCTION}

Tube heat exchangers and louvered fin are widely used in HVAC and refrigeration systems and are classified into evaporators and condensers. Many studies have been conducted in order to improve the efficiency of these heat exchangers and to save energy. In recent years, researchers have tried to develop high performance heat exchangers by changing the simple fin-and-tube heat exchangers with plain fins into advanced compact heat exchangers with louvered fins [1-6]. Louvered fins provide a number of interrupting surfaces which interact with boundary layers to form a complex flow pattern that increases the heat transfer rate. Therefore, investigating the effect of louvered fin geometry on fluid flow and heat transfer is extremely important for designing an efficient heat exchanger.

Marlow et al. [7] explored the inlet region of louvered fin heat exchangers. Their research indicated that the area of this inlet region depends on a particular geometry. They showed the existence of frequency components in the flow behind a fully-developed louver. By varying the geometrical parameters, Karthik et al. [8] performed experimental and parametric analyses in order to study the thermo hydraulic performance of a compact heat exchanger with louvered fins. They showed that the increase in both the transverse and longitudinal tube pitches can lead to a higher pressure drop at un-louvered fin surfaces. Cuevas et al. [9] used Kandlikar classification to investigate the thermo-hydraulic performance of a louvered fin and flat tube minichannel heat exchanger. Pega et al. [10] studied the effect of louver angle on the performance of a heat exchanger with serpentine fins and flat tubes in a refrigeration system. They found that, with the increase of louver angle, the pressure drop at the beginning of the first frosting cycle increases for all fin pitches. Jang and Chen [11] numerically studied the optimization of louver angle in a louvered-fin heat exchanger. To predict the timevarying performance of folded louvered fins in microchannel heat exchangers, a model was developed which successfully predicts the amount of heat transfer in these systems [12]. The transient and steady-state flow conditions in heat exchangers with double-row and triple-row multi-louvered fins were investigated in order to estimate the performance of these heat exchangers [13].

Vaisi et al. [14] studied the effect of geometry optimization on the performance of a compact louvered-fin heat exchanger. They investigated the air-side heat transfer and pressure drop characteristics of flow over louvered fins and found out that by increasing the number of louvered fins in each tube row, the amount of heat transfer rate increases. Also, they analyzed the effects of different geometrical parameters including louver angle, louver pitch, number of louvers, non-louvered length of fin inlet and outlet, and redirection distance on the heat transfer and pressure drop characteristics of compact louvered fin-and-tube heat exchangers experimentally and numerically [15]. Dong et al. [16] obtained a correlation between heat transfer and pressure drop for different types of compact heat exchangers with multi-louvered fins. Their results showed that fin pitch and fin length have significant effects on heat transfer coefficient and pressure drop as a function of forward air velocity.

The effect of transverse tube pitch on the heat transfer performance of compact heat exchangers was numerically 
investigated by $\mathrm{Hu}$ et al. [17]. Their results show that at the same forward inlet air velocity in a heat exchanger, the overall average Nusselt number and pressure drop are reduced by increasing the transverse tube pitch. Ryu et al. [18] presented heat transfer and fluid flow correlations that express the performance of heat exchangers with corrugated louvered fins. They numerically investigated the effects of friction factor $f$ and Colburn factor $j$ associated with corrugated louvered fins. The air-side fluid flow and heat transfer characteristics of a multi-row fin-and-tube heat exchanger with flat and louvered fins were analyzed by Carija et al. for a wide range of operating conditions [19]. They found out that louver length has the greatest influence on heat transfer capacity. The effects of the different parameters of a multi-louvered-fin heat exchanger with delta-winglet vortex generators on heat transfer and pressure drop under laminar flow conditions were analyzed by Dezan et al. [20]. The fluid flow and heat transfer characteristics of compact heat exchangers with single- and double-row flat tubes and louvered fins were numerically simulated by Malapure et al. [21]. They found that the local Nusselt number is substantially high at fin tips and at the leading and trailing edges of louvers. Numerical Study on Heat Transfer Enhancement in a Rectangular Duct with Incline Shaped Baffles were numerically studied by Parkpoom et al. [22]. They found that the optimum $\mathrm{Re}$ is 12600 and degree is 45.

A review of recent literature on the effects of geometrical parameters on the thermo-hydraulic performance of fin-andtube heat exchangers indicate that no related numerical analysis has been performed on the simultaneous effects of different parameters such as louver length, fin height and fintube contact thickness. Therefore, in this work, a fin-and-tube heat exchanger prototype has been manufactured and tested experimentally. The experimental tests were conducted for a few cases, and the obtained heat transfer rates and pressure drop coefficients were evaluated. After comparing the experimental and the numerical simulation results for some cases, several models were investigated numerically to observe the effect of each geometrical parameter on heat exchanger performance. A computer program based on the $\varepsilon-N T U$ method was also prepared to calculate the outlet temperature and pressure drop in the air section, and the numerical results were compared with the results obtained by the $\varepsilon-N T U$ model.

\section{MATHEMATICAL ANALYSIS}

\subsection{Physical model}

Fig. 1 shows the schematic model of the test radiator and the top and front sectional views. The arrangement of fins and tube in the test core can be seen in this figure. Because of the periodic and symmetric configuration of the test core, only one fin pitch in the spanwise direction of air flow and one water tube pitch in the lateral direction have been considered as the computational domain.

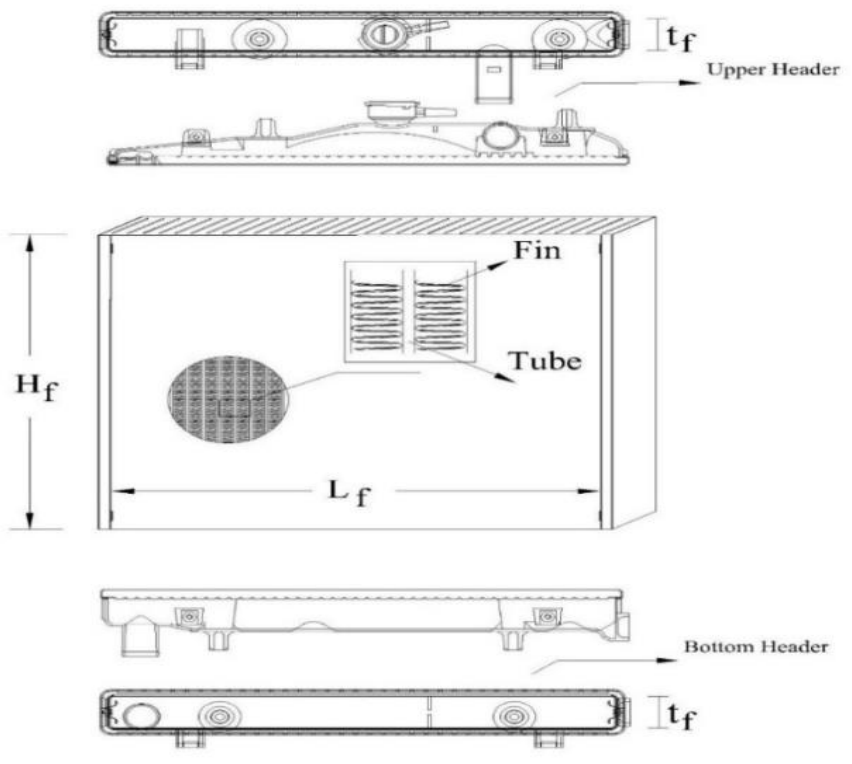

Figure 1. General view of finned tube compact heat exchanger

\subsection{Governing equations}

The governing equations for a 3D steady-state flow include the following continuity, momentum and energy equations:

Mass conservation:

$\frac{\partial}{\partial x_{i}}\left(\rho u_{i}\right)=0$

Momentum equation:

$\frac{\partial}{\partial x_{i}}\left(\rho u_{i} u_{j}\right)=\frac{\partial}{\partial x_{i}}\left(\mu\left(\frac{\partial u_{j}}{\partial x_{i}}+\frac{\partial u_{i}}{\partial x_{j}}\right)\right)-\frac{\partial p}{\partial x_{j}}$
Energy equation:

$\frac{\partial}{\partial x_{i}}\left(\rho C_{p} u_{i} T\right)=\frac{\partial}{\partial x_{i}}\left(k \frac{\partial T}{\partial x_{i}}\right)$

In the above equations, $u_{i}, T, \mathrm{P}, \rho, \mu, C_{p}, k$ indicate the mean velocity, temperature, pressure, density, dynamic viscosity, specific heat and thermal conductivity, respectively. In order to obtain the flow streamlines, pressure drop and temperature fields, the equations of continuity, momentum and energy are solved using the CFD techniques. Laminar and incompressible flow and constant air properties are assumed in solving these equations. 


\subsection{Numerical simulation and boundary conditions}

In this paper, a 3D problem of fluid flow over a louvered fin of a finned-tube heat exchanger has been studied. The geometrical parameters and the configuration of louvered fins are depicted in Fig. 2, in which $x, y$ and $z$ are the streamwise, normal and spanwise coordinates, respectively. The height, length and width of computational domain are $1.25 \mathrm{~mm}$, $25 \mathrm{~mm}$ and $4.58 \mathrm{~mm}$, respectively. As Fig. 2 illustrates, each fin element between water tubes includes an inlet louver and an outlet louver with opposite directions. The middle surfaces of two adjacent fins are chosen as the upper and lower boundaries of a louver element. For side boundaries, the midsection of water tubes on both sides of a louver element are considered as the left and right boundaries of the computational domain in the spanwise direction. Periodic boundary conditions are applied at the top and bottom as well as the left and right sides of the computational domain. The computational domain is extended by a distance of $5 \mathrm{~F}_{\mathrm{p}}$ along the entrance upstream of the louver element and a distance of
$15 \mathrm{~F}_{\mathrm{p}}$ downstream of the louver element in order to avoid inlet and outlet flow influences and to be able to use fully developed flow conditions at the outlet.

Because of using elliptic governing equations, the conditions of all the boundaries must be considered in the computational domain. No-slip boundary conditions with zero flow velocity and constant wall temperature $T_{w}=353 \mathrm{~K}$ are considered at louvered fin surfaces. A temperature of $T_{\text {in }}=$ $293 \mathrm{~K}$ and a uniform flow velocity of $u_{\text {in }}=12 \mathrm{~m} / \mathrm{s}$ along a distance of 5Fp upstream of a louver element are established as the inlet boundary conditions. For outlet boundary conditions, Neumann boundary conditions (defined as a streamwise gradient of zero) are considered for all the variables along a distance of $15 \mathrm{Fp}$ downstream of a louver element. Moreover, wall boundary conditions are assumed for the two sides of louver element, and periodic boundary conditions are applied at the upper and lower bounds of the computational domain.

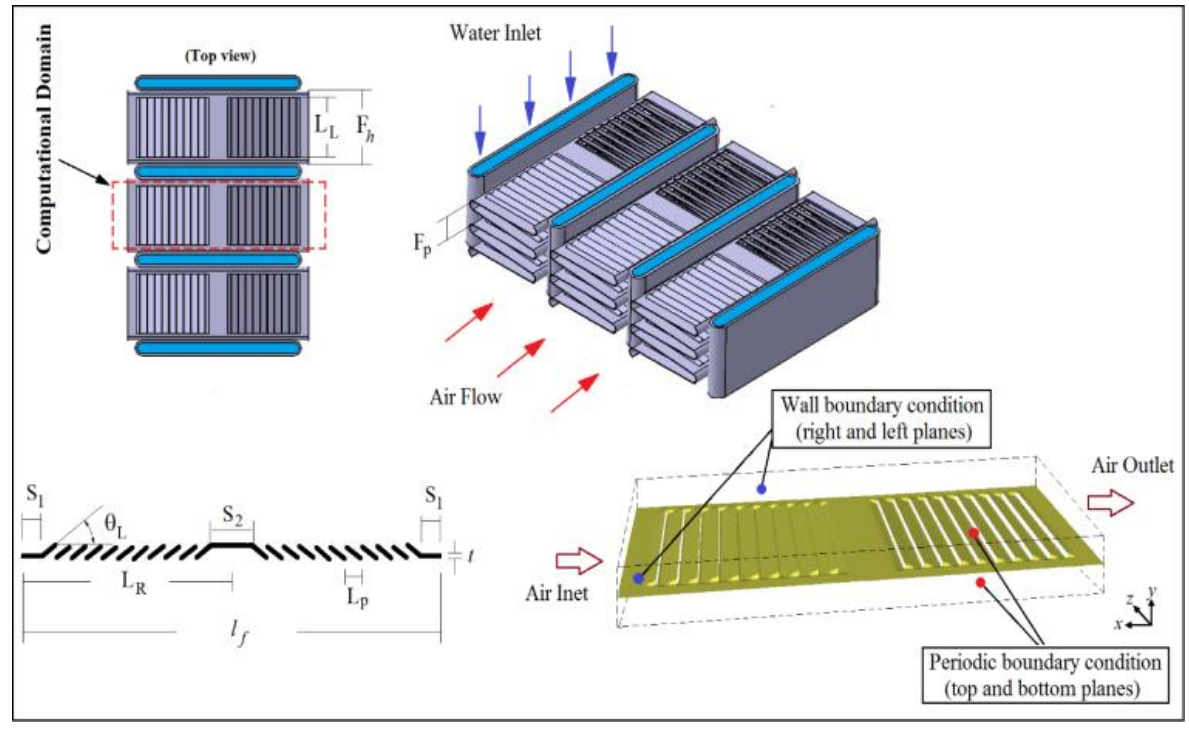

Figure 2. General view of louvered fin

In simulating this problem, an unstructured mesh with conical quadrilateral cells has been used along with a numeric Open Foam solver. The discretization of momentum and energy equations is performed by employing the second-order 'Upwind' method, and the discretization of the pressure term in the momentum equation is carried out by using the Bristho technique. The energy equation has been discretized implicitly, and the coupling of velocity and pressure fields by means of the 'Simple' method has been used to correct the pressure field. In numerical simulations, the under relaxation coefficients are used to further stabilize the iterative method. The correct selection of these coefficients totally depends on the experience gained by solving various problems. The subrelaxation coefficients for the equations of pressure, momentum and energy have been considered as $0.3,0.5$ and 0.85 , respectively.

\subsection{Definition of performance parameters}

The dimensionless pressure coefficient and heat transfer rate for the air side are obtained from the following equations:

$$
\begin{aligned}
& C_{f}=\frac{\Delta p}{\frac{1}{2} \rho u_{i n}^{2} \frac{l_{f}}{D_{h f}}} \\
& Q=\rho u_{\text {in }} A_{c} C_{p}\left(T_{a, \text { out }}-T_{a, \text { in }}\right)
\end{aligned}
$$

where $\Delta p, u_{\text {in }}, \mathrm{l}_{\mathrm{f}}, \mathrm{D}_{\mathrm{hf}}, T_{a, \text { in }}$ and $A_{c}$ are the air side pressure drop, inlet velocity, fin length, hydraulic diameter of flow cross section, inlet air temperature, outlet air temperature and the cross sectional area of flow on the air side, respectively. The heat transfer coefficient and the Nusselt number, $\mathrm{Nu}$, by using the logarithmic mean temperature difference (LMTD) method, are determined as:

$$
\begin{aligned}
& h_{c}=\frac{Q}{A \Delta T_{m}} \\
& N u=\frac{h_{c} F_{p}}{k}
\end{aligned}
$$

where $\Delta T_{m}$ (LMTD) is defined as:

$\Delta T_{m}=\frac{\left(\Delta T_{\text {out }}-\Delta T_{\text {in }}\right)}{\ln \left(\Delta T_{\text {out }} / \Delta T_{\text {in }}\right)}=\frac{\left(T_{f, \text { in }}-T_{a, \text { in }}\right)-\left(T_{f, \text { out }}-T_{a, \text { out }}\right)}{\ln \left(\left(T_{f, \text { in }}-T_{a, \text { in }}\right) /\left(T_{f, \text { out }}-T_{a, \text { out }}\right)\right)}$ 
$T_{f, \text { in }}, T_{f, \text { out }}, F_{p}$ and $A$ denote the fin temperature at the inlet, fin temperature at the outlet, fin pitch, and the total surface area, respectively. The air side heat transfer and pressure drop are calculated by applying the $\varepsilon-N T U$ method. The number of transfer units $(N T U)$ can be obtained by the following equation:

where:

$$
\begin{aligned}
& N T U=\frac{U A}{C_{\text {min }}} \\
& \varepsilon=\frac{\dot{Q}}{\dot{Q}_{\max }} \\
& C_{r}=\frac{C_{\text {min }}}{C_{\text {max }}}
\end{aligned}
$$

where:

$$
\begin{aligned}
& U A=\frac{\dot{Q}}{\Delta T_{m}} \\
& C_{\text {min }}=\min \left(C_{h}, C_{c}\right) \\
& C_{\text {max }}=\max \left(C_{h}, C_{c}\right) \\
& Q_{\text {max }}=C_{\text {min }}\left(T_{h, l n}-T_{c, l n}\right)
\end{aligned}
$$

The heat exchanger efficiency is used for perpendicular flow with two non-mixed fluids using the following equation [22]:

$$
\varepsilon=1-\exp \left[\left(\frac{1}{c_{r}}\right)(N T U)^{0.22}\left\{\exp \left[-C_{r}(N T U)^{0.78}\right]-1\right\}\right]
$$

\section{EXPERIMENTAL SETUP}

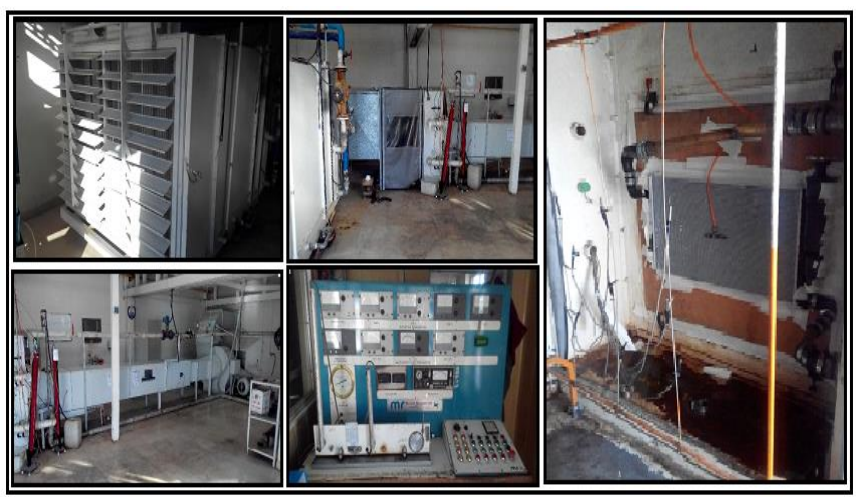

Figure 3. A view of experimental setup

Fig. 3 shows the apparatus of the experimental equipment used in this investigation. The examined heat exchanger is placed in a test rig comprising an open air channel (including a test section, a laminar flow element, and a motor-controlled ventilator) and a closed water cycle. The galvanized steel air channel has a cross section of $800 \times 800 \mathrm{~mm}^{2}$. In the openloop wind tunnel, air is circulated by a variable-speed centrifugal fan which is driven by a frequency-controlled motor. Using this mechanism, different mass flow rates of air can be produced. At the air channel inlet, a liquid-to-air heat exchanger is used to cool the air temperature. In the closed- loop water cycle, cold water is circulated by a rotary gear pump, and the water temperature is controlled via a thermal conditioning system. The cooling air enters the test section and flows through the louvered fin-and-tube heat exchanger (The geometric specifications of the heat exchanger are listed in Table 1). The heat exchanger itself is placed in a separate frame within the test section. In order to reduce heat losses that may affect temperature measurements, this frame and subsequent measuring units are completely insulated by foam panels. Measurements are taken at both the inlet and outlet of the heat exchanger. The test section is also carefully insulated to eliminate heat losses between measuring stations. The temperatures of heat exchangers at the inlet and outlet are measured by means of $12 \mathrm{~K}$-type thermocouples. Once the tunnel reaches steady state, an average of 180 temperature measurements are taken at each thermocouple location. The pressure drop across the test section is measured by using two pressure transducer calibrated to an accuracy of $\pm 0.09 \%$. One of these transducers is placed at heat exchanger inlet and the other is positioned after the laminar flow element. To obtain the pressure drops across the louvered array and the laminar flow element, 1100 and 6500 sample measurements are taken and averaged, respectively. For every air velocity, roughly, 350 measurements are averaged to obtain the air-side pressure drop. A mass flow meter $( \pm 0.5 \%)$ is used to obtain the flow rate of air at the heat exchanger outlet. A laminar flow element with a 2:1 nozzle area reduction is placed after the test section to provide a uniform flow. The flow rates through the test section are measured by means of a laminar flow element. A single-phase mixture of ethylene glycol and water is used for flow measurements in the water-side of heat exchanger. This cycle consists of K-type thermocouples, an electronic flow meter, a circulation pump, thermal conditioning, manometer and a differential pressure transducer. A water boiler and a gear pump supply the hot fluid for the heat exchanger in the test section; and a thermal conditioner controls the temperature of this hot water. The water temperatures at the inlet and outlet are measured by K-type thermocouples, which are read by a scanner and a high precision voltmeter. The pressure drops in the water-side are measured by a differential pressure transducer and checked by a manometer.

Table 1. Geometrical parameters of the louvered fin-andtube heat exchanger

\begin{tabular}{c|c}
\hline \multicolumn{2}{c}{ Parameters } \\
\hline Tube material & Aluminum \\
\hline Tube surface area $\left(\mathrm{mm}^{2}\right)$ & $2.1 \times 22.93$ \\
\hline Tube thickness $(\mathrm{mm})$ & 0.28 \\
\hline Core width $(\mathrm{mm})$ & 383 \\
\hline Number of tube rows in the airflow & 1 \\
\hline Fin material & Aluminum \\
\hline Fin thickness $(\mathrm{mm})$ & 0.07 \\
\hline Fin height $(\mathrm{mm})$ & 9.17 \\
\hline Fin depth $(\mathrm{mm})$ & 25 \\
\hline Louver length $(\mathrm{mm})$ & 7.4 \\
\hline Louver pitch $(\mathrm{mm})$ & 1 \\
\hline Louvers per tube row & 18 \\
\hline Louver angle $($ degree $)$ & 24 \\
\hline Header to header length $(\mathrm{mm})$ & 320 \\
\hline Fpm & 2.5 \\
\hline Air flow re-direction length $(\mathrm{mm})$ & \\
\hline
\end{tabular}




\section{RESULTS AND DISCUSSION}

In this section, the effects of different geometrical parameters on the thermal performance of a heat exchanger have been studied.

\subsection{Validation}

In addition to simulating fluid flows and evaluating the heat transfer and pressure drop features of heat exchangers using the CFD method, the obtained results are compared with experimental data for several cases in order to validate the numerical simulations. For this purpose, an aluminum louvered fin-and-tube heat exchanger prototype is manufactured and tested in a wind tunnel. For all the performed simulations, the mass flow rate of water is $\dot{m}=$ $40 \mathrm{lit} / \mathrm{min}$, inlet water temperature is $\mathrm{T}=80^{\circ} \mathrm{C}$ and the inlet air temperature is $T=20^{\circ} \mathrm{C}$. In order to validate the numerical results, an experimental model was fabricated and tested. Unstructured meshing with conical quadrilateral cells has been used in the numerical simulations performed in the present work. For mesh independency, several grids with different numbers of meshes were employed. The outlet temperature and pressure coefficient were examined for grids which the independence of solution from quantity of mesh was selected.

The experimental model was placed in a wind tunnel and its performance was evaluated under different boundary conditions. The results of several tests on the prototype, under different conditions, were compared with the simulation results. After validating the numerical results, several models were numerically simulated and studied for different geometries and boundary conditions. As Table 2 and Fig. 4 indicate, the experimental and numerical results are in good agreement. Assuming the same temperature for the meshed surfaces of heat exchanger in the numerical models of all tubes and fins, from top to bottom and assuming a perpendicular direction to flow, a 3D element at the beginning and one at the end of the tube are analyzed.

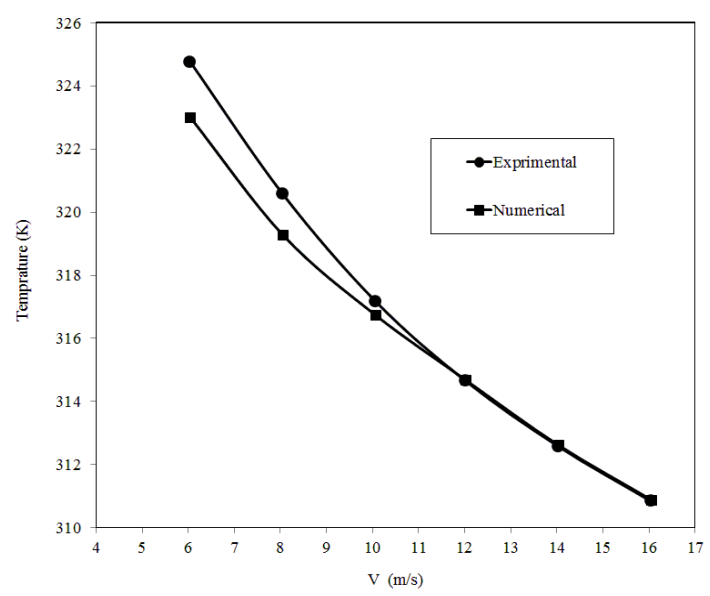

Figure 4. Comparison of the experimental and numerical temperature profile of the fluid in different inlet velocities

According to these results, the average outlet flow (air) temperature decreases almost linearly by increasing the inlet velocity. The results also indicate that at lower air velocities, the error between experimental and numerical results is rather large, and that it diminishes at higher air velocities. Because of the good match between the results in Tables 3 and 4, several models with different geometries and boundary conditions were simulated numerically to demonstrate the effects of different geometrical parameters on the performance of louvered fin heat exchangers. The maximum and minimum percentage errors between experimental and numerical results are $3.51 \%$ and $0.13 \%$ for temperature, $8.75 \%$ and $4.54 \%$ for friction coefficient, respectively.

Table 2. The variation of outlet air temperature with inlet air velocity

\begin{tabular}{cccc}
\hline $\begin{array}{c}\text { Inlet } \\
\text { airvelocity } \\
(\mathbf{m} / \mathbf{s})\end{array}$ & $\begin{array}{c}\text { Exp. Outlet } \\
\text { air } \\
\text { temperature } \\
(\mathbf{C})\end{array}$ & $\begin{array}{c}\text { Num. Outlet } \\
\text { air } \\
\text { temperature } \\
(\mathbf{C})\end{array}$ & Error $(\%)$ \\
\hline 6.04 & 49.86 & 51.61 & \\
8.05 & 46.13 & 47.42 & 2.51 \\
10.06 & 43.59 & 44.06 & 1.08 \\
12.02 & 41.53 & 41.44 & 0.22 \\
14.03 & 39.47 & 39.42 & 0.13 \\
16.04 & 37.92 & 37.68 & 0.62 \\
\hline
\end{tabular}

\subsection{The effect of fin-tube contact thickness}

In order to illustrate different parameters such as the Nusselt number and pressure drop coefficients in the same figure, these parameters are non-dimensionalized with respect to their maximum value, as $\mathrm{f} / \mathrm{f}_{\max }$, and the results are presented in a range of [0-1]. Fig. 5 shows the effect of fin-tube contact thickness on pressure drop coefficient and Nusselt number. As this figure indicates, by increasing the fin-tube contact thickness as high as the fin thickness ( 7 microns), the amount of heat transfer increases and then decreases; but the coefficient of friction at first increases to the contact thickness and then remains constant. The increase of fin-tube contact thickness enhances the rate of heat transfer between fin surfaces as fluid passes through the fins. Due to the fact that in the range of the contact thickness to the tube, which is more than the thickness of the fin, the heat is transferred from the tube to the fluid and in which the flow range does not pass through the blade, there is no time of heat transfer to other points. Also, by increasing the thickness, the surface of contact between fin and fluid is reduced, especially at the fin-tube contact zone, and pressure drop is increased. At fin-tube contact thicknesses greater than fin thickness ( 7 microns), there is no significant change in the amount of pressure drop.

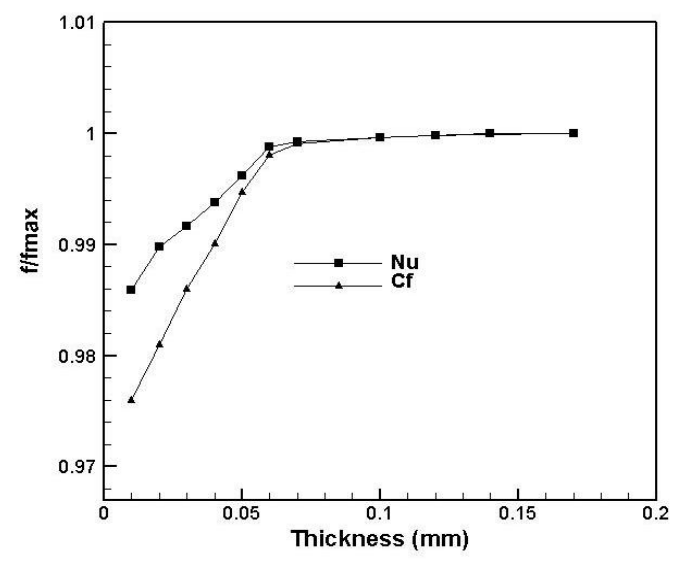

Figure 5. The non-dimensional variation of Nusselt number and pressure drop coefficient at different thickness of the fin contact surface 
Fig. 6 shows the changes of fluid temperature at the start of louvered fins, as the fin-tube contact surface increases. As it is observed in this figure, by increasing the fin-tube contact thickness, fin surface increases, thereby increasing the amount of heat conduction and heat transfer between fin and fluid. Due to the constant inlet temperature, fluid temperature rises where the louvered fins begin.

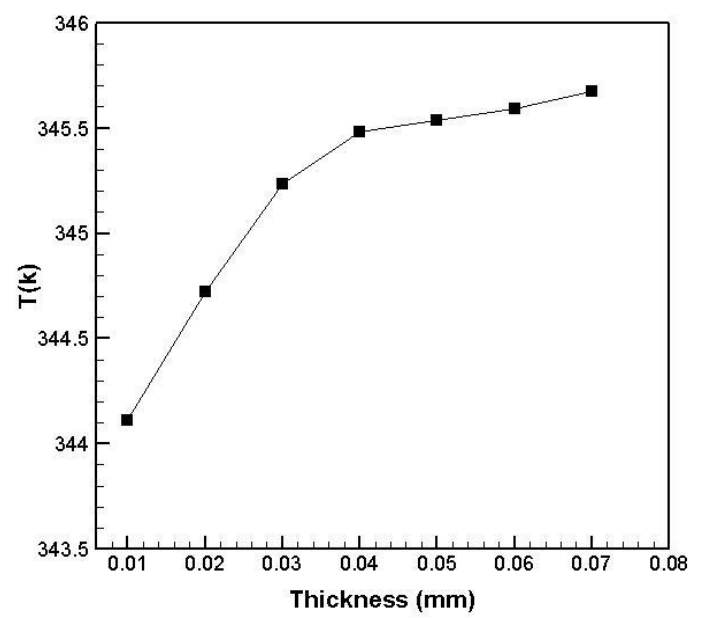

Figure 6. The variation of fluid temperature at the start of the Louvre fin at different thickness of the fin contact surface

\subsection{The effect of louver length}

Figs. 7 and 8 show the variations of louver length with fin height. With the increase of louver length, the suction and blowing cross sections in fins increase. Thus, a larger volume of fluid passes through the fins and thereby, the rate of heat exchange between fins and fluid increases. Consequently, the amount of heat transfer and pressure drop increases. However, for mechanical strength reasons, louver length should be at least $1.0 \mathrm{~mm}$ less than fin height. According to the results, at louver lengths of 7.8, 6.6 and $5.7 \mathrm{~mm}$ and fin heights of 9.17 , 8 and $7 \mathrm{~mm}$, respectively, the amount of heat transfer increases first and then diminishes or remains almost unchanged.

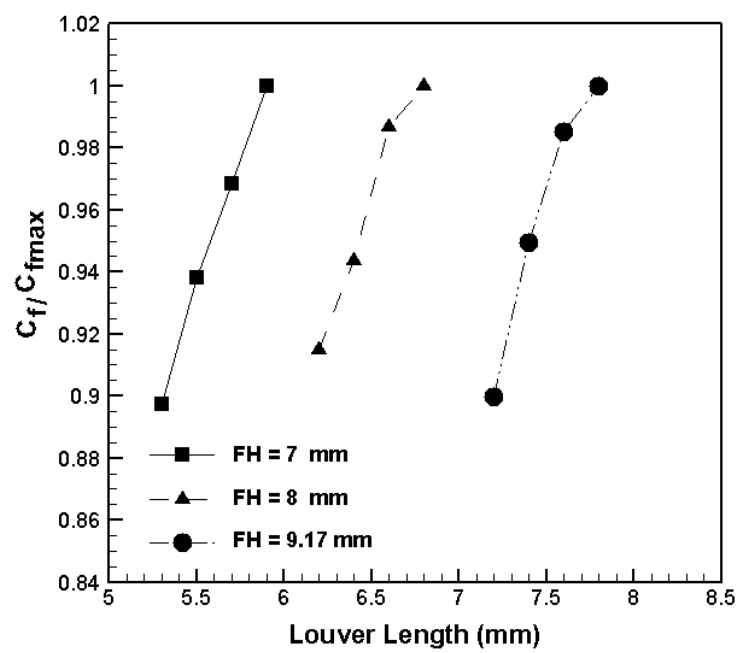

Figure 7. The non-dimensional variation of pressure drop coefficient at different louver length for difference fin height

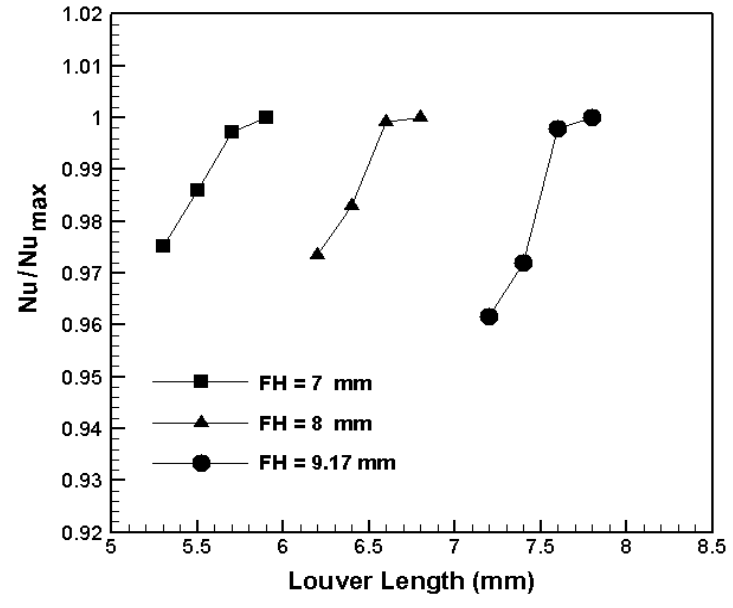

Figure 8. The non-dimensional variation of Nusselt number at different louver length for difference fin height

Fig. 9 shows the temperature distribution obtained by changing the louver length and keeping the fin height constant at $8 \mathrm{~mm}$. With the increase of louver length, heat transfer and outlet fluid temperature increase first and then remain almost constant. Because suction and blowing flow rates go up with the increase of louver length, the volume of fluid passing through the ducts increases, and more energy is transferred. However, with the increased duct length, the side area of tubes becomes too small. This not only diminishes the mechanical strength, but it also reduces the volume of fluid required for heat transfer with the fins; and so there is less energy transfer.

Fig. 10 shows the pressure distribution caused by varying the louver length and keeping the fin height constant at $8 \mathrm{~mm}$. Pressure drop increases with the increase of louver length; because of increasing the cross sections of suction and blowing flows. Because the volume of fluid passing through the cross sections and the contact surface increases, which increases the coefficient of friction and pressure drop. Also, the volume of fluid passing through the channels is greater than the change of contact thickness; and this increases the coefficient of friction and pressure drop. Also, the volume of fluid passing through these cross sections and the contact surface increase, which increase the coefficient of friction and pressure drop. Fig. 14 shows the variation of temperature profile in the $x-$ direction. It can be seen the fluid temperature increases with along x-direction.

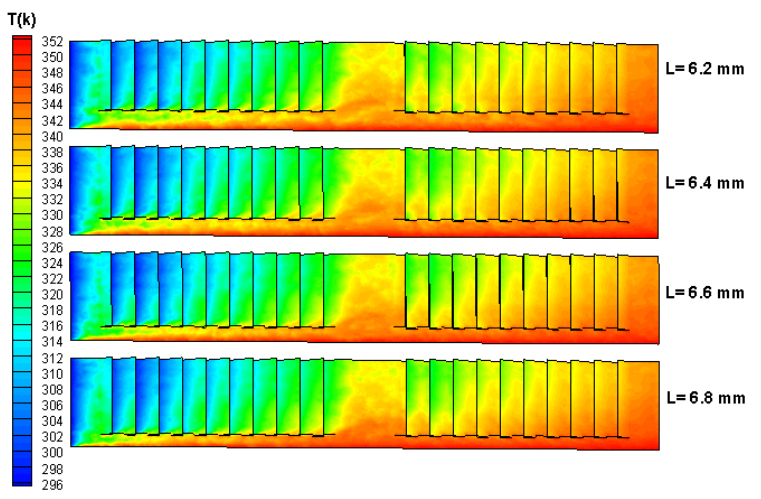

Figure 9. Temperature contours at mid-plane of louver domain for different louver length 


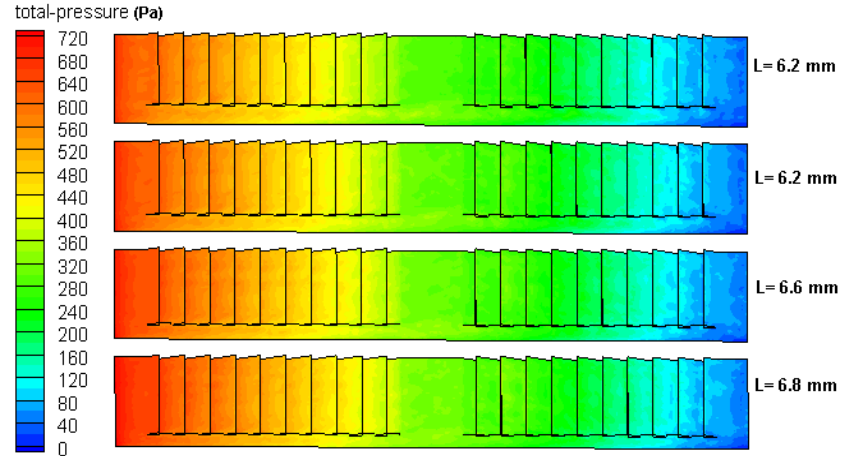

Figure 10. Pressure drop contours at mid-plane of louver domain for different louver length
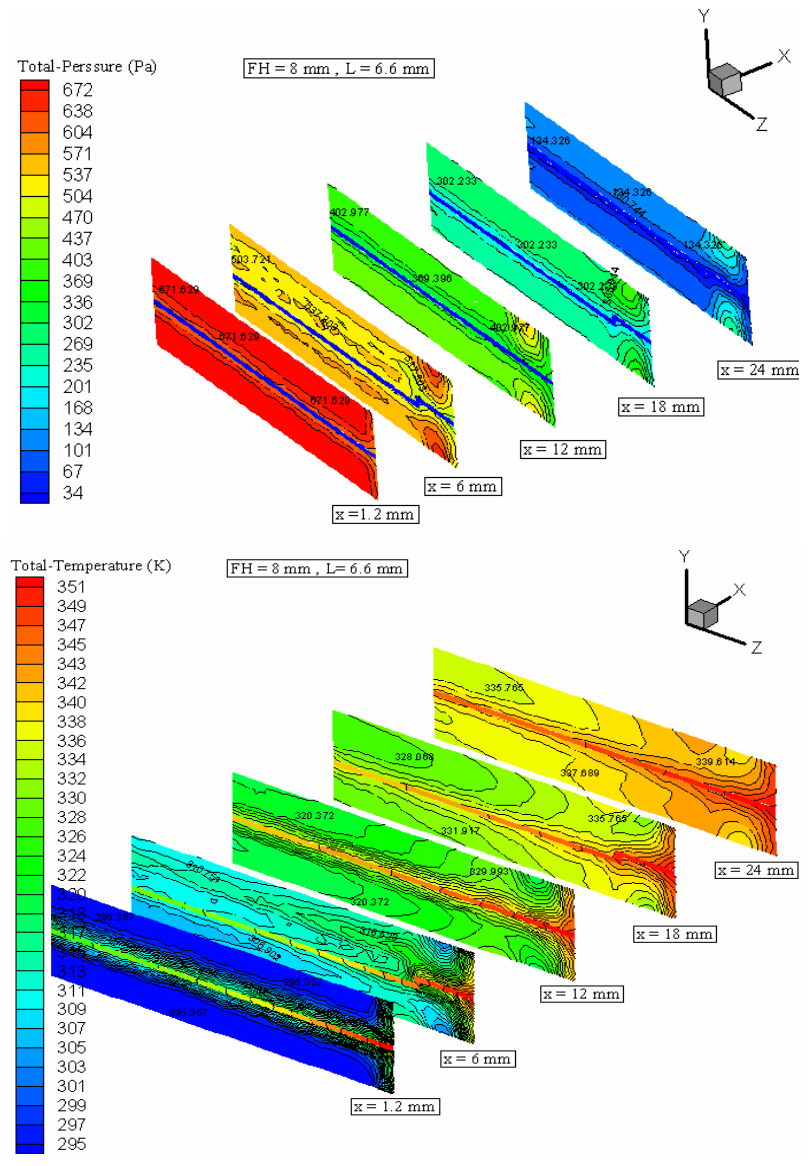

Figure 11. The profile of temperature and pressure in $\mathrm{x}$ direction $(\mathrm{x}=1.2,6,12,18$ and $24 \mathrm{~mm})$ at $\mathrm{FH}=8 \mathrm{~mm}$ and $\mathrm{L}$ $=6 \mathrm{~mm}$

\subsection{The effect of inlet Reynolds number}

By changing the inlet Reynolds number, the variations of temperature and pressure contours on fin have been investigated. As the Reynolds number increases, the rate of flow passing over the fins becomes greater. Also, the increase of Reynolds number leads to the increase of convection heat transfer between fin surface and fluid flow. Also, with regards to the amount of heat transfer according to Eq. 5 and the constant inlet fluid temperature, the outlet fluid temperature is reduced according to Fig. 12. In view of Eq. 4, due to the increase of flow velocity, the pressure fluctuations on fin increase with the increase of Reynolds number, according to Fig. 13.

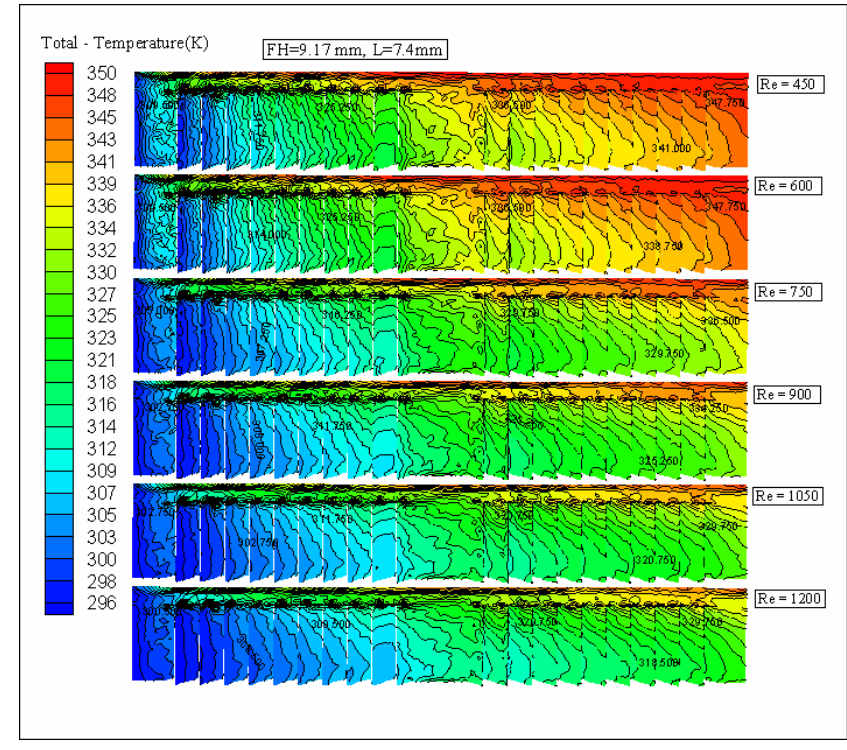

Figure 12. Temperature contours at mid-plane of louver domain for different Reynolds number

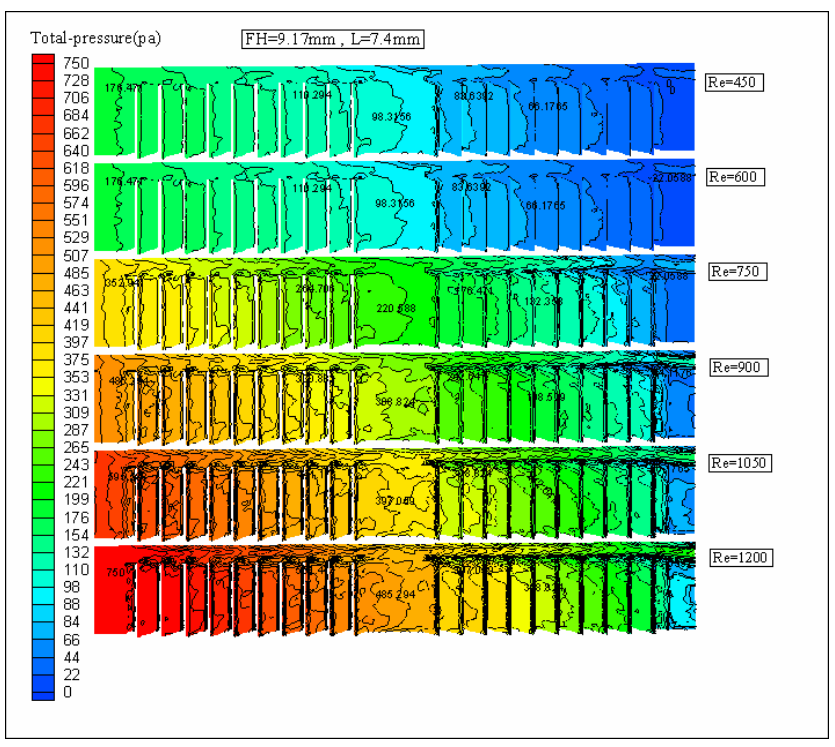

Figure 13. Pressure drop contours at mid-plane of louver domain for different Reynolds number

\subsection{The effect of fin height (length of inlet stream)}

Fig. 14 shows the variations of outlet fluid temperature versus the ratio of louver length to fin height. By increasing the ratio of louver length to fin height, the rate of heat transfer between fin surface and fluid is increased, thereby raising the outlet fluid temperature. Also, at a constant ratio of louver length to fin height, the outlet fluid temperature decreases with the increase of fin height; this reduces the heat transfer and outlet fluid temperature, because the fluid passing over the fins does not have enough time for the exchange and transfer of heat with the fins.

Figure 15 shows the changes of dimensionless pressure drop versus the ratio of louver length to fin height. With the increase in the ratio of louver length to fin height, pressure drop increases, because the volume of the fluid passes through increasing the cross-section with the blowing and the suction, the surface of the contact with the Louvre fin increases. In addition, at a constant ratio of louver length to fin height, pressure drop diminishes with the increase of fin height. 


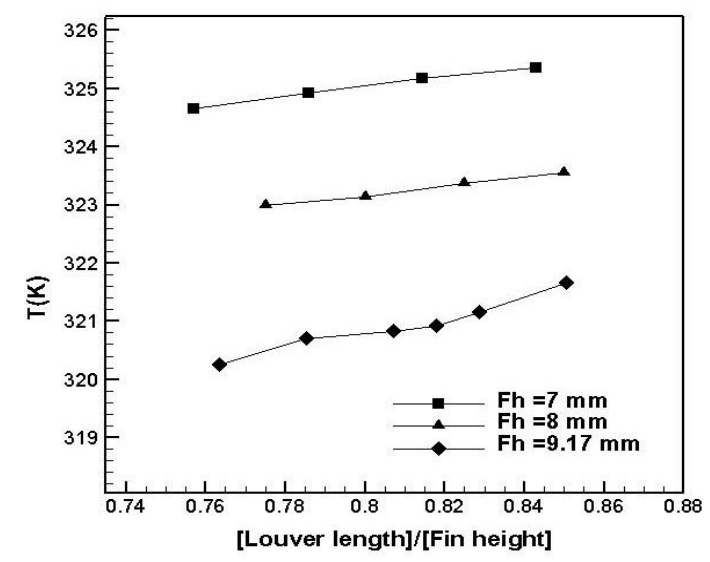

Figure 14. The variation of outlet fluid temperature at different with the ratio of Louvre length to the fin height

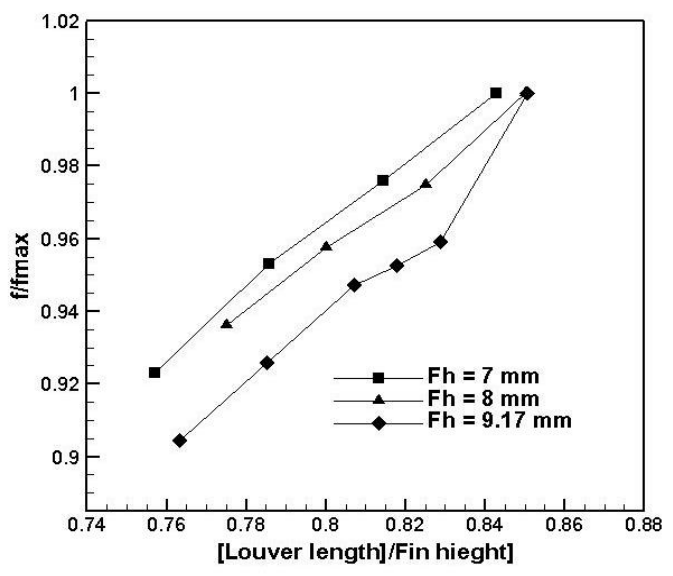

Figure 15. The non-dimensional variation of presser coefficient at different with the ratio of Louvre length to the fin height

Figure 16 shows the optimal louver length versus the fin height. By increasing the fin height the optimal louver length is also increased. However, these changes increase the ratio of optimal louver length to fin height (which is between 0.75 and $0.85 \mathrm{~mm}$ ), and this change of optimal louver length to fin height can be indicated as an analytical equation. Based on experimental and numerical results, a correlation was proposed for variation in the height of the fin versus variations in the length Louvers.

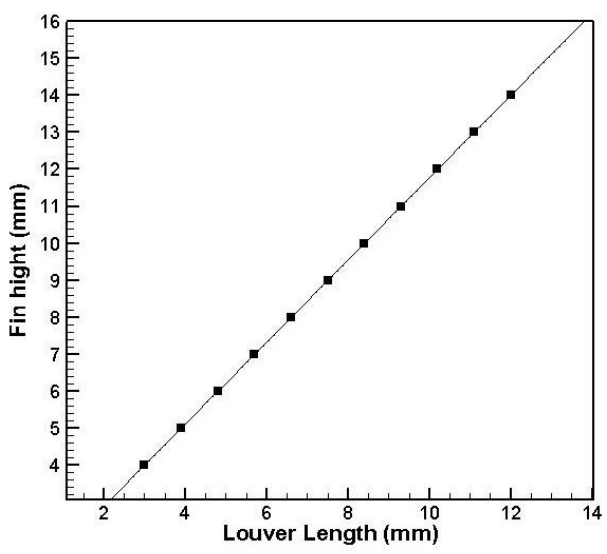

Figure 16. The variation of optimization louver length at different fin height
Using the MATLAB code and the correlations between experimental and numerical data, some formulas were derived that relate fin height to louver length. After applying a genetic algorithm to minimize error (least square method), Eq. 17 was obtained for this purpose.

$\mathrm{F}_{\mathrm{h}}=0.66666+1.11111 L_{L}+0.0000000127 L_{L}{ }^{2}$

In this equation, $L_{L}$ is the louver length and $F_{h}$ is the fin height.

This numerical modeling can be optimized for any louver length. The presented equation showed up to $98 \%$ agreement with the experimental and numerical models. In Table 3, louver lengths at different fin heights obtained experimentally and analytically have been compared. The fin heights obtained in terms of optimal louver length closely match the actual fin heights used in the industry.

Table 3. The variation of fin height with different louver length

\begin{tabular}{ccc}
\hline $\begin{array}{c}\text { louver length } \\
(\mathbf{m} \boldsymbol{m})\end{array}$ & $\begin{array}{c}\text { Real fin height } \\
(\mathbf{m} \boldsymbol{m})\end{array}$ & $\begin{array}{c}\text { Calculate fin height } \\
(\mathbf{m} \boldsymbol{m})\end{array}$ \\
\hline 3 & 4 & 3.99 \\
3.9 & 5 & 4.99 \\
4.8 & 6 & 6.00 \\
5.7 & 7 & 7.00 \\
6.6 & 8 & 8.00 \\
7.5 & 9 & 9.00 \\
8.4 & 10 & 10.00 \\
9.3 & 11 & 11.00 \\
10.2 & 12 & 12.00 \\
11.1 & 13 & 12.99 \\
12 & 14 & 13.99 \\
\hline
\end{tabular}

\section{CONCLUSION}

In this work, the effects of fin height, optimal louver length and fin-louver contact thickness on the amount of heat transfer and pressure drop in a compact heat exchanger were investigated. The variable parameters included the fin-tube contact thickness, louver length and fin height. For validation, several experimental tests were conducted in a wind tunnel facility, and a good agreement was observed between the experimental and numerical results.

The conclusions of this research can be summarized as follows:

1. The amounts of heat transfer and pressure drop increase by increasing the fin-tube contact thickness up to the fin thickness; a further increase in the fin-tube contact thickness has no effect on heat exchanger performance.

2. By increasing the ratio of louver length to fin height, the amounts of heat transfer and pressure drop are increased.

3. At a constant ratio of louver length to fin height, the amounts of heat transfer and pressure drop diminish with the increase of fin height.

4. For the sake of mechanical strength, louver length should be at least $1.0 \mathrm{~mm}$ less than fin height. Considering both the experimental and numerical results, a formula relating louver length to fin height has been derived that agrees up to $98 \%$ with the modeling results.

5. The optimal louver lengths of 5.7, 6.6 and $7.6 \mathrm{~mm}$ are obtained for fin heights of 7,8 and $9.17 \mathrm{~mm}$, respectively.

6. The ratio of optimal louver length to fin height is 
approximately 0.82 .

\section{ACKNOWLEDGMENTS}

The authors would like to express gratitude to Jalal Manouchehrian and Ebrahim Kahinpour, two senior Managers of Radiator Iran Company, for the close cooperation and supporting this work.

\section{REFERENCES}

[1] Khoshvaght-Aliabadi M, Hormozi F, Zamzamian A. (2014). Role of channel shape on performance of platefin heat exchangers: Experimental assessment. International Journal of Thermal Sciences 79: 183-193. http://dx.doi.org/10.1016\%2Fj.ijthermalsci.2014.01.004

[2] Liang YY, Liu CC, Li CZ, Chen JP. (2015). Experimental and simulation study on the air side thermal hydraulic performance of automotive heat exchangers. Applied Thermal Engineering 87: 305-315. http://dx.doi.org/10.1016\%2Fj.applthermaleng.2015.05. 018

[3] Tian M. (2018). Research on features of heat spatial distribution for heat exchanger of automobile engine bay and improvement model. Chemical Engineering Transactions 66: 391-396. https://doi.org/10.3303/CET1866066

[4] Petrik M, Szepesi GL. (2018). Shell side CFD analysis of a model shell-and-tube heat exchanger. Chemical Engineering Transactions 70: 313-318. https://doi.org/10.3303/CET1870053

[5] Jahromi AB, Mitra NK, Biswas G. (1999). Numerical investigations on enhancement of heat transfer in a compact fin-and-tube heat exchanger using delta winglet type vortex generators. Journal of Enhanced Heat Transfer 6(1): 1-11. https://doi.org/10.1615/JEnhHeatTransf.v6.i1.10

[6] Aoki H, Shinagawa T, Suga K. (1989). An experimental study of the local heat transfer characteristics in automotive louvered fins. Experimental Thermal and Fluid Science 2(3): 293-300. https://doi.org/10.1016/0894-1777(89)90018-6

[7] Springer ME, Thole KA. (1999). Entry region of louvered fin heat exchangers. Experimental Thermal and Fluid Science 19(4): 223-232. https://doi.org/10.1016/S0894-1777(99)00028-X

[8] Karthik P, Kumaresan V, Velraj R. (2015). Experimental and parametric studies of a louvered fin and flat tube compact heat exchanger using computational fluid dynamics. Alexandria Engineering Journal 54(4): $905-$ 915. https://doi.org/10.1016/j.aej.2015.08.003

[9] Cuevas C, Makaire D, Dardenne L, Ngendakumana P. (2011). Thermo-hydraulic characterization of a louvered fin and flat tube heat exchanger. Experimental Thermal and Fluid Science 35(1): 154-164. https://doi.org/10.1016/j.expthermflusci.2010.08.015

[10] Pega HPZ, Chris R. (2012). Effect of Louver Angle on Performance of Heat Exchanger with Serpentine Fins and Flat Tubes in Periodic Frosting. International Journal of Refrigeration 84: 321-335. https://doi.org/10.1016/j.ijrefrig.2017.08.002
[11] Jang JY, Chen CC. (2015). Optimization of louvered-fin heat exchanger with variable louver angles. Applied Thermal Engineering 91: 138-150. https://doi.org/10.1016/j.applthermaleng.2015.08.009

[12] Xia Y, Jacobi A M. (2010). A model for predicting the thermal-hydraulic performance of louvered-fin, flat-tube heat exchangers under frosting conditions. International Journal of Refrigeration 33(2): 321-333. https://doi.org/10.1016/j.ijrefrig.2009.09.021

[13] Dogan B, Altun Ö, Ugurlubilek N, Tosun M, Sarıçay T, Erbay L B. (2015). An experimental comparison of two multi-louvered fin heat exchangers with different numbers of fin rows. Applied Thermal Engineering 91: 270-278. https://doi.org/10.1016/j.applthermaleng.2015.07.059

[14] Vaisi A, Esmaeilpour M, Taherian H. (2011). Experimental investigation of geometry effects on the performance of a compact louvered heat exchanger. Applied Thermal Engineering 31(16): 3337-3346. https://doi.org/10.1016/j.applthermaleng.2011.06.014

[15] Javaherdeh K, Vaisi A, Moosavi R, Esmaeilpour M. (2017). Experimental and numerical investigations on louvered fin-and-tube heat exchanger with variable geometrical parameters. ASME, Journal of Thermal Science and Engineering Applications 9(2): 024501024501-024508. DOI: 10.1115/1.4035449

[16] Dong J, Chen J, Chen Z, Zhang W, Zhou Y. (2007). Heat transfer and pressure drop correlations for the multilouvered fin compact heat exchangers. Energy Conversion and Management 48(5): 1506-1515. https://doi.org/10.1016/j.enconman.2006.11.023

[17] Hu WL, Wang LB, Guan Y. (2015). The effect of transverse tube pitch on the thermal-hydrodynamic performance of a circular tube-plate-fin heat exchanger with fin-mounted vortex generation. Journal of Enhanced Heat Transfer 22(3): 221-246. https://doi.org/10.1615/JEnhHeatTransf.2015014211

[18] Ryu K, Lee KS. (2015). Generalized heat-transfer and fluid-flow correlations for corrugated louvered fins. International Journal of Heat and Mass Transfer 83: 604612.

https://doi.org/10.1016/j.ijheatmasstransfer.2014.12.044

[19] Čarija Z, Franković B, Perčić M, Čavrak M. (2014). Heat transfer analysis of fin-and-tube heat exchangers with flat and louvered fin geometries. International Journal of Refrigeration 45: 160-167. https://doi.org/10.1016/j.ijrefrig.2014.05.026

[20] Dezan DJ, Salviano LO, Yanagihara JI. (2015). Interaction effects between parameters in a flat-tube louvered fin compact heat exchanger with delta-winglets vortex generators. Applied Thermal Engineering 91: 1092-1105. https://doi.org/10.1016/j.applthermaleng.2015.08.072

[21] Malapure VP, Mitra SK, Bhattacharya A. (2007). Numerical investigation of fluid flow and heat transfer over louvered fins in compact heat exchanger. International Journal of Thermal Sciences 46(2): 199211. https://doi.org/10.1016/j.ijthermalsci.2006.04.010

[22] Sriromreun P, Sriromreun P. (2017). Numerical study on heat transfer enhancement in a rectangular duct with incline shaped baffles. Chemical Engineering Transactions 57:1243-1248. https://doi.org/10.3303/CET1757208 


\section{NOMENCLATURE}

$A$

$A_{c}$

C

$C_{p}$

$C_{r}$

$D_{h f}$

$F_{h}$

$F_{p}$

$h_{c}$

$H_{f}$

$k$

LMTD

$l_{f}$

$L_{f}$

$L_{L}$

$L_{P}$

$L_{R}$

$N_{L}$

$\mathrm{Nu}$

NTU

$p$

$\Delta p$ [K] [mm]
Total surface area $\left[\mathrm{m}^{2}\right]$

Cross section air flow $\left[\mathrm{m}^{2}\right]$

Heat capacity rate $[\mathrm{J} / \mathrm{kg} \mathrm{K}]$

Specific heat [J/kg K]

Capacity rate ratio [-]

Hydraulic diameter [mm]

Fin height [mm]

Fin pitch [mm]

Heat transfer coefficient $\left[\mathrm{W} / \mathrm{m}^{2} \mathrm{~K}\right]$

Radiator height [mm]

Thermal conductivity [W/m K]

Logarithmic mean temperature difference

Fin length [mm]

Radiator width [mm]

Louver height [mm]

Louver pitch [mm]

Distance of inlet and re-direction region

Louver number [-]

Nusselt number [-]

Number of transfer unit [-]

Pressure [Pa]

Pressure drop $[\mathrm{Pa}]$
$U A \quad$ Overall thermal conductivity [W/ K]

$\dot{Q} \quad$ Heat transfer rate [W]

$S_{1} \quad$ Non-louvered inlet and exit fin length [mm]

$S_{2} \quad$ Re-direction length [mm]

$t \quad$ Fin thickness [mm]

$T \quad$ Temperature [K]

$t_{f} \quad$ Fin depth in flow direction [mm

$u \quad$ Velocity [m/s]

\section{Greek symbols}

$\begin{array}{ll}\varepsilon & \text { Effectiveness } \\ \theta_{L} & \text { Louver angle }\left[{ }^{\circ}\right] \\ \mu & \text { Dynamic viscosity }\left[\mathrm{Ns} / \mathrm{m}^{2}\right] \\ \rho & \text { Density }\left[\mathrm{kg} / \mathrm{m}^{3}\right]\end{array}$

\section{Subscripts}

$\begin{array}{ll}a & \text { Air } \\ c & \text { Cold } \\ f & \text { Fin } \\ h & \text { Hot } \\ \text { in } & \text { Inlet } \\ \max & \text { Maximum } \\ \text { min } & \text { Minimum } \\ \text { out } & \text { Outlet }\end{array}$

